\title{
Distribution and bioaccumulation of lead in the coastal watersheds of the Northern Bohai and Yellow Seas in China
}

\author{
Peiru Kong • Wei Luo • Yonglong Lu • Tieyu Wang • Wentao Jiao • \\ Wenyou Hu $\cdot$ Jonathan E. Naile $\cdot$ Jong Seong Khim $\cdot$ John P. Giesy
}

Received: 15 March 2014/ Accepted: 27 November 2014/Published online: 12 December 2014

(C) Springer Science+Business Media Dordrecht 2014

\begin{abstract}
In this study, the concentration of lead $([\mathrm{Pb}])$ in the surface water, sediments, soils and muscles of carp and crab in the upstream and downstream coastal watersheds along the Northern Bohai and Yellow Seas (NBYS) in China was investigated and the risks of $\mathrm{Pb}$ were evaluated. The mean $[\mathrm{Pb}]$ in the downstream water $(2.62 \mu \mathrm{g} / \mathrm{L})$ and sediments $[24.5 \mathrm{mg} / \mathrm{kg}$, dry mass $(\mathrm{dm})]$ was greater than the Chinese seawater quality standard for class I $(1 \mu \mathrm{g} / \mathrm{L})$ and the regional background soil concentration (11.5 mg Pb/kg, dm), respectively. Approximately $37 \%$ of the soils, mainly from the upstream regions, had $[\mathrm{Pb}]$ greater than the regional background concentration of $21.4 \mathrm{mg} / \mathrm{kg}$, dm. The sites with relatively large $[\mathrm{Pb}]$ in the water, sediments and soils were located in the coastal watersheds of Tangshan and Huludao. The large enrichment factors in the
\end{abstract}

P. Kong · W. Luo $(\bowtie) \cdot$ Y. Lu · T. Wang ·

W. Jiao · W. Hu

State Key Lab of Urban and Regional Ecology, Research

Center for Eco-Environmental Sciences, Chinese

Academy of Sciences, Beijing 100085, China

e-mail: luow@rcees.ac.cn

P. Kong

Graduate University of Chinese Academy of Sciences,

Beijing, China

J. E. Naile · J. S. Khim · J. P. Giesy

Department of Veterinary Biomedical Sciences and

Toxicology Centre, University of Saskatchewan,

Saskatoon, Canada sediments (2.41) and soils (2.22) suggested that human activities influenced the soils and sediments in this region more than in the other regions. Relatively large $[\mathrm{Pb}]$ was found in the crabs that were obtained from the upstream reaches of the Shuanglong and Daliao Rivers and the downstream reaches of the Luanhe and Liugu Rivers. Most of the crabs from the upstream regions contained greater $[\mathrm{Pb}]$ than the permissible limit for human consumption $[0.3 \mathrm{mg} / \mathrm{kg}$, wet mass (wm)]. The risk indices of the water, carp and crabs for humans were 0.002, 0.01 and 0.006, respectively. Based on the bioaccumulation factors, biota-sediment accumulation factors (BSAFs) and human risk indices, it was concluded that the human risks associated with crab were lower than those of carp despite the greater accumulation of $\mathrm{Pb}$ by the crabs from the water and sediments. Finally, the $[\mathrm{Pb}]$ in the sediments was significantly correlated with the $[\mathrm{Pb}]$ in the soils,




which indicated that the same sources of $\mathrm{Pb}$ were responsible for the $[\mathrm{Pb}]$ in the sediments and soils in the coastal watersheds of the NBYS in China.

Keywords Pollution - Watersheds - Enrichment factor $\cdot$ Human $\cdot$ Risk index $\cdot$ Asia

\section{Introduction}

More than $70 \%$ of large Chinese cities are located in coastal areas. The development of these cities in China has played an important role in the national economy, accounting for $55 \%$ of its gross domestic productivity (GDP). However, as the human population continued to increase and economic growth occurred, rapid urbanization and infrastructure development resulted in the pollution of some coastal regions, especially in the estuaries of major rivers (Segura et al. 2006). Urbanization and industrialization are accompanied by greater lead $(\mathrm{Pb})$ emissions from automobiles and industry to the surrounding environments (Arnason and Fletcher 2003). Therefore, primary sources of $\mathrm{Pb}$ emissions include transportation, treated urban effluents, agricultural runoff and urban runoff (Ona et al. 2006; Gobeil et al. 2005). Unfortunately, $\mathrm{Pb}$ is toxic to humans, especially children, and wildlife. Human health can be affected by the atmospheric deposition of $\mathrm{Pb}$ and its enrichment in the food chain. One of the most serious environmental problems that occurs in coastal areas and threatens the sustainability of the coastal areas of China is the increasing rate of $\mathrm{Pb}$ emissions, which subsequently results in the contamination of biotic and abiotic matrices with $\mathrm{Pb}$ (Wang et al. 2010; Dong et al. 2009).

The Bohai and Yellow Seas are located in a coastal area with intense human activity. Specifically, approximately $20 \%$ of China's population resides in this region and approximately $25 \%$ of China's gross domestic productivity (GDP) is attributed to this region (Luo et al. 2010). Because large amounts of industrial and municipal effluents contain $\mathrm{Pb}$ and because other metals have entered the offshore environment of the Bohai and Yellow Seas (Jiang et al. 2014; Gao and Chen 2012), several coastal watersheds along the Bohai and Yellow Seas have been polluted with $\mathrm{Pb}$ (Zheng et al. 2008; Tao 2006). The northern portions of the Bohai and Yellow Seas contain the most $\mathrm{Pb}$ contamination. However, previous studies were focused on downstream areas, including the estuaries, coasts and bays along the Northern Bohai and Yellow Seas (NBYS) in China, and the status and distribution of $\mathrm{Pb}$ pollution in the upstream areas of these coastal watersheds have remained unexplored; thus, it is difficult to assess the risks associated with $\mathrm{Pb}$ and to determine its sources. Furthermore, the differences in the $\mathrm{Pb}$ concentrations $([\mathrm{Pb}])$ in the water, sediments, soils and biota between the upstream and downstream areas of the coastal watersheds along the NBYS are largely unknown at a regional scale (Feng et al. 2011; Wang and Wang 2007). Thus, a gap in understanding exists regarding the transport of $\mathrm{Pb}$ from the upstream reaches of the rivers to the estuaries and the coastal regions of the NBYS in China. To develop strategies for controlling pollution and systematic approaches for managing $\mathrm{Pb}$ transported by inland rivers to the NBYS, information regarding the input, transport, and accumulation of $\mathrm{Pb}$ and the geochemical distribution of $\mathrm{Pb}$ within the coastal watersheds along the NBYS is needed.

The objectives of this study were as follows: (1) to determine the $[\mathrm{Pb}]$ in the water, sediments, soils and biota in the upstream areas of coastal rivers and in the downstream receiving water at a watershedlevel scale along the NBYS in China; (2) to characterize the spatial distribution of the $[\mathrm{Pb}]$ in the water, soils, sediments and biota and to determine the bioaccumulation of $\mathrm{Pb}$ along the NBYS; and (3) to evaluate the potential sources of $\mathrm{Pb}$ and its potential effects on the coastal environment and human health in China.

\section{Materials and methods}

Study area

Two catchments exist for the coastal rivers along the NBYS in China (Fig. 1; Table 1). The Northern Bohai Sea (NBS) collects water from the rivers west of Dalian, and the Northern Yellow Sea (NYS) collects water from the rivers east of Dalian. The Liugu, Wuli, Daling, Liaohe, Daliao, Daqing and Fuzhou Rivers flow north to south into the NBS, while the other rivers flow north to south into the NYS. Twenty-eight million people live in the coastal watersheds along 




Fig. 1 Sampling sites for the surface waters, sediments and biota upstream and downstream in the rivers along the coastal areas of the Northern Bohai and Yellow Seas (NBYS) in China 
Table 1 Sample details and surrounding activities for all sampling sites along the Northern Bohai and Yellow Seas (NBYS) in China

\begin{tabular}{|c|c|c|c|c|c|c|c|c|c|c|c|}
\hline \multicolumn{4}{|l|}{ Sampling } & \multicolumn{4}{|c|}{ Samples } & \multicolumn{4}{|c|}{ Land uses } \\
\hline Sea & Coastal region & River/Sea & Sites & Water & Sediment & Soil & Biota & A & I & M & $\mathrm{O}$ \\
\hline \multirow[t]{12}{*}{ Northern Bohai Sea } & \multirow[t]{7}{*}{ Tangshan } & Dou River & TS1 & $\mathrm{C}$ & $\mathrm{C}$ & $\mathrm{C}$ & $\mathrm{C}$ & $\mathrm{C}$ & & & \\
\hline & & Qionglong River & TS2 & $\mathrm{C}$ & $\mathrm{C}$ & $\mathrm{C}$ & $\mathrm{C}$ & $\mathrm{C}$ & & & \\
\hline & & Bohai Sea & TS3 & $\mathrm{C}$ & $\mathrm{C}$ & $\mathrm{NC}$ & $\mathrm{C}$ & $\mathrm{C}$ & & & \\
\hline & & Shuanglong River & TS4 & $\mathrm{C}$ & $\mathrm{C}$ & $\mathrm{C}$ & $\mathrm{NC}$ & $\mathrm{C}$ & & & \\
\hline & & Bohai Sea & TS5 & $\mathrm{C}$ & $\mathrm{C}$ & $\mathrm{C}$ & $\mathrm{C}$ & & & & $\mathrm{C}$ \\
\hline & & Luan River & TS6 & $\mathrm{C}$ & $\mathrm{C}$ & C & $\mathrm{NC}$ & $\mathrm{C}$ & & & \\
\hline & & Luan River & TS7 & $\mathrm{C}$ & $\mathrm{C}$ & C & $\mathrm{NC}$ & $\mathrm{C}$ & & & \\
\hline & \multirow[t]{5}{*}{ Qinhuangdao } & Bohai Sea & QH1 & $\mathrm{C}$ & $\mathrm{C}$ & $\mathrm{NC}$ & $\mathrm{C}$ & & & & $\mathrm{C}$ \\
\hline & & Xin River & QH2 & $\mathrm{C}$ & $\mathrm{C}$ & $\mathrm{C}$ & $\mathrm{C}$ & $\mathrm{C}$ & & & \\
\hline & & Xin River & QH3 & $\mathrm{C}$ & $\mathrm{C}$ & $\mathrm{NC}$ & $\mathrm{C}$ & $\mathrm{C}$ & & & $\mathrm{C}$ \\
\hline & & Bohai Sea & QH4 & $\mathrm{C}$ & $\mathrm{C}$ & $\mathrm{C}$ & $\mathrm{C}$ & & & & $\mathrm{C}$ \\
\hline & & Tianma River & QH5 & $\mathrm{C}$ & $\mathrm{C}$ & $\mathrm{C}$ & $\mathrm{C}$ & & & & \\
\hline \multirow[t]{18}{*}{ (Liaodong Bay) } & \multirow[t]{5}{*}{ Huludao } & Bohai Sea & HL1 & $\mathrm{C}$ & $\mathrm{C}$ & $\mathrm{NC}$ & $\mathrm{C}$ & & & & $\mathrm{C}$ \\
\hline & & Liugu River & HL2 & $\mathrm{C}$ & $\mathrm{C}$ & $\mathrm{C}$ & $\mathrm{NC}$ & $\mathrm{C}$ & & & \\
\hline & & Liugu River & HL3 & $\mathrm{C}$ & $\mathrm{C}$ & $\mathrm{C}$ & $\mathrm{C}$ & $\mathrm{C}$ & & & \\
\hline & & Wuli River & HL4 & $\mathrm{C}$ & $\mathrm{C}$ & C & $\mathrm{NC}$ & & $\mathrm{C}$ & & \\
\hline & & Bohai Sea & HL5 & $\mathrm{C}$ & $\mathrm{C}$ & $\mathrm{C}$ & $\mathrm{C}$ & & & & $\mathrm{C}$ \\
\hline & \multirow[t]{5}{*}{ Jinzhou } & Xiaoling River & $\mathrm{JZ1}$ & $\mathrm{NC}$ & $\mathrm{NC}$ & $\mathrm{C}$ & $\mathrm{NC}$ & & & $\mathrm{C}$ & \\
\hline & & Daling River & JZ2 & $\mathrm{C}$ & $\mathrm{C}$ & $\mathrm{C}$ & $\mathrm{C}$ & & & $\mathrm{C}$ & \\
\hline & & Daling River & $\mathrm{JZ3}$ & $\mathrm{C}$ & $\mathrm{C}$ & $\mathrm{C}$ & $\mathrm{NC}$ & $C$ & & & \\
\hline & & Daling River & $\mathrm{JZ4}$ & $\mathrm{C}$ & $\mathrm{C}$ & $\mathrm{C}$ & $\mathrm{NC}$ & & $\mathrm{C}$ & & \\
\hline & & Bohai Sea & JZ5 & $\mathrm{C}$ & $\mathrm{C}$ & $\mathrm{C}$ & $\mathrm{NC}$ & $\mathrm{C}$ & & & \\
\hline & \multirow[t]{2}{*}{ Panjin } & Shuangtaizi River & PJ1 & $\mathrm{C}$ & $\mathrm{C}$ & $\mathrm{C}$ & $C$ & $\mathrm{C}$ & & & \\
\hline & & Bohai Sea & PJ2 & $\mathrm{C}$ & $\mathrm{C}$ & $\mathrm{C}$ & $\mathrm{C}$ & & & & $\mathrm{C}$ \\
\hline & \multirow[t]{3}{*}{ Yingkou } & Daliao River & YK1 & $\mathrm{C}$ & $\mathrm{C}$ & $\mathrm{C}$ & $\mathrm{NC}$ & & & $\mathrm{C}$ & \\
\hline & & Bohai Sea & YK2 & $\mathrm{C}$ & $\mathrm{C}$ & C & $\mathrm{C}$ & & & $\mathrm{C}$ & \\
\hline & & Bohai Sea & YK3 & $\mathrm{C}$ & $\mathrm{C}$ & $\mathrm{C}$ & $\mathrm{C}$ & & & & $\mathrm{C}$ \\
\hline & \multirow[t]{3}{*}{ Dalian } & Bohai Sea & DL1 & $\mathrm{C}$ & $\mathrm{C}$ & $\mathrm{C}$ & $\mathrm{C}$ & $C$ & & & \\
\hline & & Fuzhou River & DL2 & $\mathrm{C}$ & $\mathrm{C}$ & $\mathrm{C}$ & $\mathrm{C}$ & & & & $\mathrm{C}$ \\
\hline & & Bohai Sea & DL4 & $\mathrm{C}$ & $\mathrm{C}$ & $\mathrm{NC}$ & $\mathrm{NC}$ & & & & $\mathrm{C}$ \\
\hline \multirow[t]{7}{*}{ Northern Yellow Sea } & & Yellow Sea & DL3 & $\mathrm{C}$ & $\mathrm{NC}$ & $\mathrm{NC}$ & $\mathrm{C}$ & & & $\mathrm{C}$ & \\
\hline & & Biliu River & DL5 & $\mathrm{C}$ & $\mathrm{C}$ & $\mathrm{C}$ & $\mathrm{NC}$ & $\mathrm{C}$ & & & \\
\hline & & Yellow Sea & DL6 & $\mathrm{C}$ & $\mathrm{C}$ & $\mathrm{C}$ & $\mathrm{C}$ & & & & $\mathrm{C}$ \\
\hline & \multirow[t]{4}{*}{ Dandong } & Dayang River & DD1 & $\mathrm{C}$ & $\mathrm{C}$ & $\mathrm{C}$ & $\mathrm{NC}$ & $\mathrm{C}$ & & & \\
\hline & & Yalu River & DD2 & $\mathrm{C}$ & $\mathrm{C}$ & $\mathrm{C}$ & $\mathrm{NC}$ & $\mathrm{C}$ & & & \\
\hline & & Yellow Sea & DD3 & $\mathrm{C}$ & $\mathrm{C}$ & C & $\mathrm{C}$ & & $\mathrm{C}$ & & \\
\hline & & Yalu River & DD4 & $\mathrm{C}$ & $\mathrm{C}$ & $\mathrm{C}$ & $\mathrm{NC}$ & & & & $\mathrm{C}$ \\
\hline
\end{tabular}

$C$ collected, $N C$ not collected, $A$ agricultural, $I$ industrial, $M$ municipal, $O$ others

the NBYS, with the watersheds in Tangshan containing most of the human population. The coastal watersheds in Jinzhou and Panjin contain the largest areas of farmland among the considered watersheds.
The largest rural and industrialized areas occurred in the watersheds in Tangshan and Dalian, where the largest amounts of industrial waste and sewage are discharged. 
Sampling

All samples were collected in October 2008 (Table 1). Thirty-six surface water samples were collected from 36 different sites in the coastal watersheds along the NBYS in China (Fig. 1). In addition, 21 water samples were obtained from the upstream areas of the rivers, and 15 samples were collected from the downstream areas. Each water sample consisted of five homogenized sub-samples $(1 \mathrm{~L})$ that were collected at depths of $0-10 \mathrm{~cm}$ from an area of approximately $25 \mathrm{~m}^{2}$. Next, the samples were placed into pre-cleaned and labeled Teflon bottles. To maintain the dissolved metals in solution, the samples were filtered through a $0.45-\mu \mathrm{m}$ capsule filter and acidified with $\mathrm{HNO}_{3}$ to a $\mathrm{pH}$ of $\leq 2$ immediately following collection. The acidified samples were placed in a cooler and immediately delivered to the laboratory. Clean sampling techniques were used during the sample collection, preservation and storage (Patterson and Settle 1976).

Except for one location, the surface sediment samples were collected synoptically from the same where water was collected. Next, 35 sediment samples were collected. Among these samples, 21 were from the upstream areas and 14 were from the downstream areas (Fig. 1). Each sediment sample was composed of five homogenized sub-samples that were collected from the top $10 \mathrm{~cm}$ of sediment within an area of $5 \mathrm{~m}^{2}$. The composite sediment samples were placed in darkcolored Teflon bottles, refrigerated and immediately returned to the laboratory. In the laboratory, the samples were air-dried, crushed, thoroughly mixed and passed through a 100-mesh nylon sieve before storing at $4{ }^{\circ} \mathrm{C}$ in the dark until analysis.

Next, 31 surface soil samples were collected from most of the sites where the water was collected. Among these samples, 21 were from the upstream areas and 10 were from the downstream areas (Fig. 1). At each sampling site, five subsamples $(0-20 \mathrm{~cm}$ depth) were collected (at four vertexes and the center of a square block) and were thoroughly mixed before obtaining $1 \mathrm{~kg}$ of the soil as a representative sample. The soils were air-dried, crushed, thoroughly mixed and passed through a 100-mesh nylon sieve in the laboratory.

Crucian carp (Carassius carassius) and Asian shore crabs (Hemigrapsus sanguineus) were selected as representative aquatic foods because their habitats are evenly distributed throughout the coastal areas along the NBYS. To remove the effects of size between the individuals of the same species, only individuals that were approximately the same size were collected. The collected Crucian carp had an average length of $9 \pm 2 \mathrm{~cm}$ (mean $\pm \mathrm{SD}$ ) and an average wet mass of $180 \pm 30 \mathrm{~g}$ (mean $\pm \mathrm{SD}$; estimated average age 1-2 years). In addition, the collected Asian shore crabs had an average carapace width of $3.2 \pm 0.40 \mathrm{~cm}$ (mean $\pm \mathrm{SD}$ ) and an average wet mass of $20 \pm 3 \mathrm{~g}$ (mean $\pm \mathrm{SD}$; estimated average age 1-2 years). Composite samples of the carp and crab consisted of three individuals that were pooled to form one representative sample for each sampling site. Overall, 36 composite samples were obtained from 24 locations. Seven of the 13 pooled carp samples were obtained from the upstream areas, and six were obtained from the downstream areas. In addition, 5 of the 23 pooled crab samples were obtained from the upstream areas, and 18 were obtained from the downstream areas (Fig. 1; Table 1). The biota samples were placed in watertight polyethylene bags and frozen at $-20{ }^{\circ} \mathrm{C}$. These samples were dissected in the laboratory, and equal masses of the muscle samples from each replicate of the same species from each site were combined. Aliquots of the muscle samples were dried at $45{ }^{\circ} \mathrm{C}$ for $24 \mathrm{~h}$.

\section{Quantification of heavy metals}

The total concentrations of $\mathrm{Pb}$ and $\mathrm{Fe}$ in the digestates and reagent blanks were quantified using inductively coupled plasma mass spectrometry (ICP-MS). The surface water was analyzed directly, and the sediments and soils were digested with $\mathrm{HNO}_{3}$ and $\mathrm{H}_{2} \mathrm{O}_{2}$ according to USEPA Method 3051 (USEPA 1992). The dried muscles were divided into $0.10-0.45 \mathrm{~g}$ aliquots and homogenized, weighed and digested in Teflon bombs with $\mathrm{HNO}_{3}, \mathrm{H}_{2} \mathrm{O}_{2}$, and $\mathrm{HCl}$ (Kimbrough and Lauenstein 2006).

Quality assurance and quality control (QA/QC) for quantifying the $\mathrm{Pb}$ and $\mathrm{Fe}$ concentrations was obtained by analyzing duplicates, method blanks, liquid standard solutions, and certified reference materials GSS1, GB ESS1 and DORM-2 for the soil, sediment and biota, respectively. Recoveries of $\mathrm{Pb}$ from soil, sediment and biota were $96 \pm 5,98 \pm 4$ and $94 \pm 2 \%$, respectively, whereas the recoveries of $\mathrm{Fe}$ from the sediments and soils were $101 \pm 4$ and $104 \pm 3 \%$, respectively. The relative percentage difference between the sample duplicates was $<10 \%$. 
Enrichment factors

Enrichment factors (EFs) were used to determine the potential sources of metals in the riverine, estuarine and coastal environments (Sinex and Wright 1988; Feng et al. 2004). To identify anomalous metal concentrations, these concentrations were geochemically normalized to the concentrations of a conservative element, such as aluminum $(\mathrm{Al})$, iron $(\mathrm{Fe})$ or silicon ( $\mathrm{Si}$ ). Several authors have successfully used $\mathrm{Fe}$ to normalize the concentrations of metal contaminants (Baptista and Smith 2000). In this study, Fe was used as a conservative tracer to differentiate between natural and anthropogenic sources of $\mathrm{Pb}$. The metal $\mathrm{EF}$ was calculated as follows (Eq. 1; Ghrefat and Yusuf 2006):

$\mathrm{EF}=\frac{\left(\frac{\mathrm{M}}{\mathrm{Fe}}\right)_{\text {sample }}}{\left(\frac{\mathrm{M}}{\mathrm{Fe}}\right)_{\text {background }}}$

where $\mathrm{EF}$ is the enrichment factor, $\left(\frac{\mathrm{M}}{\mathrm{Fe}}\right)_{\text {sample }}$ is the ratio of the $\mathrm{Pb}$ and $\mathrm{Fe}$ concentrations in the sample, and $\left(\frac{\mathrm{M}}{\mathrm{Fe}}\right)_{\text {background }}$ is the ratio of the $\mathrm{Pb}$ and $\mathrm{Fe}$ concentrations in the background. In this study, mean [Fe] of 2,880, 34,800 and 2,880 $\mathrm{mg} / \mathrm{kg} \mathrm{dm}$ were used as the background concentrations for the riverine sediments, marine sediments and soils, respectively (Sary and Mohammadi 2012).

The EF values between 0.5 and 1.5 indicated that the normalized element resulted from crustal materials or natural processes, whereas EF values $>1.5$ suggested that the sources more likely resulted from human activities (Zhang and Liu 2002). Contamination categories were defined based on the EF values. For example, an EF value of $\leq 2$ suggested a minimal $\mathrm{Pb}$ enrichment. Alternatively, an EF value of more than two suggested various degrees of $\mathrm{Pb}$ enrichment due to human activities (Han et al. 2006).

Bioaccumulation factor (BAF) and biota-sediment accumulation factor (BSAF)

Bioaccumulation is a process in which living organisms, especially those living in water, can collect and accumulate chemicals directly from their surrounding environment and indirectly from their food. In this study, the BAF and BSAF were calculated to interpret the accumulation of metals in the biota. BAF and BSAF are defined as the ratio of the concentration of a chemical inside of an organism to the concentration of the chemical in the surrounding environment (Eq. 2).

$\mathrm{BAF}(\mathrm{BSAF})=\mathrm{C}_{\mathrm{t}} / \mathrm{C}_{\mathrm{e}}$

where $\mathrm{C}_{\mathrm{t}}$ is the $[\mathrm{Pb}]$ in the biota tissues $(\mu \mathrm{g} / \mathrm{g})$ and $\mathrm{C}_{\mathrm{e}}$ is the $[\mathrm{Pb}]$ in the surface water/sediments $(\mu \mathrm{g} / \mathrm{g})(\mathrm{Yu}$ et al. 2012; Lue et al. 2011). If BAF (BSAF) is $<1$, the organism can accumulate the chemical. However, accumulation is generally not considered as significant unless this value exceeds 100 (Lue et al. 2011).

\section{Human health risk assessment model}

The health risk index (HRI) used in this study was calculated using Eq. 3 (Gong 2009) as follows:

$\mathrm{HRI}=\mathrm{CDI} / \mathrm{RfD}$

where $\mathrm{CDI}$ is the chronic daily intake of $\mathrm{Pb}$ (Eq. 4), and $\mathrm{RfD}$ is the oral toxicity reference value of $\mathrm{Pb}$, which is $0.036 \mathrm{mg} / \mathrm{kg}$ body mass according to the USEPA.

$\mathrm{CDI}=\mathrm{C} \times \mathrm{DI} / \mathrm{BW}$

here, $\mathrm{C}$, DI and BW represent $[\mathrm{Pb}]$, the average daily intake rate and body mass, respectively (Khan et al. 2013; Wan et al. 2008). Based on a dietary survey of the Chinese, their daily amount of water intake is $2 \mathrm{~L}$. In addition, the amount of fish in their diet is 50-100 g, and the greatest crab intake is $26 \mathrm{~g}$ (Gao et al. 2006). Because people living in coastal areas consume more aquatic foods than those in inland areas, the greatest daily consumption of these items (100 g) was chosen. According to the National Physique Monitoring Report, the mean body mass of people in China is $60 \mathrm{~kg}$ (EC 2006). The exposed population was assumed to be safe when the HRI was $<1$ (Khan et al. 2013).

\section{Data analysis}

The total $[\mathrm{Pb}]$ in the water, sediments, soils, carp and crabs was log-transformed to approximate the normal probability distribution. The Shapiro-Wilk test was used to test for normality. The $t$ test for independent groups was used to test whether the concentrations of metals in the water, sediments, soils, carp and crabs from the upstream coastal watersheds were significantly different from those of the downstream coastal watersheds. Differences were considered significant at 
$p<0.05$. The correlations between the metal concentrations in the abiotic and biotic materials were determined. Pearson's correlation coefficients ( $r$ ) were calculated for several of the variable pairs. All of the statistical analyses were conducted using SPSS, version 16.0.

\section{Results and discussion}

\section{Surface water}

The mean $[\mathrm{Pb}]$ in the upstream water of the coastal rivers along the NBYS was $2.64 \mu \mathrm{g} / \mathrm{L}$ and varied over a range of $2.55-3.19 \mu \mathrm{g} / \mathrm{L}$. In contrast, the mean $[\mathrm{Pb}]$ in the downstream water was $2.62 \mu \mathrm{g} / \mathrm{L}$ and varied over a range of $2.57-2.70 \mu \mathrm{g} / \mathrm{L}$ (Table 2 ). The mean $[\mathrm{Pb}]$ was not significantly greater in the upstream water than in the downstream water $(p>0.05)$. The standard deviation $(\mathrm{SD})$ of the $[\mathrm{Pb}]$ in the upstream water was greater than that in the downstream water. The greatest $[\mathrm{Pb}](3.19 \mu \mathrm{g} / \mathrm{L})$ was observed in the water from the upstream region in the Shuanglong River in Tangshan (TS4; Fig. 2a). The $[\mathrm{Pb}]$ in the water potentially indicated the temporal effects of the industrial activities in Tangshan. The $[\mathrm{Pb}]$ in the water at Tangshan reached up to $51.3 \mu \mathrm{g} / \mathrm{L}$ due to the emissions of $\mathrm{Pb}$ from factories in the Tangshan industrial region (Cui et al. 2011). In addition, the discharge of sewage in Tangshan could account for the observed $[\mathrm{Pb}]$ in the Shuanglong River. Furthermore, the upstream water of the Yalu, Qinglong and Wuli Rivers contained relatively large [Pb] (Fig. 2a). One of the largest chemical fiber production bases in China (established in 1939) and several paper-making factories in Dandong are likely sources of $\mathrm{Pb}$ for the $\mathrm{Yalu}$ River (Gao et al. 2008). Mining and processing of manganese ( $\mathrm{Mn}$ ), molybdenum (Mo), $\mathrm{Fe}, \mathrm{Pb}$ and zinc $(\mathrm{Zn})$ in Huludao have resulted in large $[\mathrm{Pb}]$ in the Wuli River (Zhang et al. 2012; Zheng et al. 2008). The Qinglong River flows through Tangshan, Qinhuangdao and Tianjin, which include the location of the third largest industrial center in China. The wastewater discharged into the river and the atmospheric deposition of $\mathrm{Pb}$ could account for the elevated $[\mathrm{Pb}]$ in the upstream water. In all of the upstream water in the coastal rivers along the NBYS, the $[\mathrm{Pb}]$ was less than the class I Chinese surface water standard $(10 \mu \mathrm{g} / \mathrm{L})$,
Table 2 Descriptive statistics for the $\mathrm{Pb}$ concentrations in the water, sediment, soil, carp and crab samples collected from the upstream and downstream regions of the coastal watersheds along the NBYS in China

\begin{tabular}{|c|c|c|c|c|c|c|c|c|c|}
\hline & $N$ & Mean & SD & Min & Max & HRI & $\mathrm{EF}$ & BSAF & BAF \\
\hline \multicolumn{10}{|l|}{ Water $(\mu \mathrm{g} / \mathrm{L})$} \\
\hline Upstream & 21 & 2.64 & 0.14 & 2.55 & 3.19 & 0.003 & & & \\
\hline Downstream & 15 & 2.62 & 0.04 & 2.57 & 2.7 & 0.001 & & & \\
\hline Total & 36 & 2.63 & 0.11 & 2.55 & 3.19 & 0.002 & & & \\
\hline \multicolumn{10}{|c|}{ Sediment $(\mathrm{mg} / \mathrm{kg}, \mathrm{dm})$} \\
\hline Upstream & 21 & 24.92 & 9.29 & 9.5 & 43.36 & & 2.04 & & \\
\hline Downstream & 14 & 23.93 & 9.42 & 13.78 & 48.49 & & 3.01 & & \\
\hline Total & 35 & 24.52 & 9.2 & 9.5 & 48.49 & & 2.41 & & \\
\hline \multicolumn{10}{|c|}{ Soil (mg/kg, dm) } \\
\hline Upstream & 21 & 40.23 & 37.76 & 16.79 & 164.58 & & 2.6 & & \\
\hline Downstream & 10 & 23.48 & 7.27 & 10.55 & 37.19 & & 1.46 & & \\
\hline Total & 31 & 34.83 & 31.09 & 10.55 & 164.58 & & 2.22 & & \\
\hline \multicolumn{10}{|c|}{ Carp (mg/kg, wm) } \\
\hline Upstream & 10 & 0.24 & 0.28 & 0.04 & 0.95 & 0.01 & & 0.01 & 92.86 \\
\hline Downstream & 7 & 0.25 & 0.25 & 0.07 & 0.79 & 0.01 & & 0.01 & 95.84 \\
\hline Total & 17 & 0.25 & 0.26 & 0.04 & 0.95 & 0.01 & & 0.01 & 94.09 \\
\hline \multicolumn{10}{|c|}{ Crab (mg/kg, wm) } \\
\hline Upstream & 6 & 0.58 & 0.27 & 0.22 & 0.88 & 0.01 & & 0.03 & 218.79 \\
\hline Downstream & 22 & 0.26 & 0.27 & 0.0024 & 1.03 & 0.005 & & 0.01 & 102.53 \\
\hline Total & 28 & 0.33 & 0.26 & 0.0024 & 1.03 & 0.006 & & 0.02 & 128.37 \\
\hline
\end{tabular}




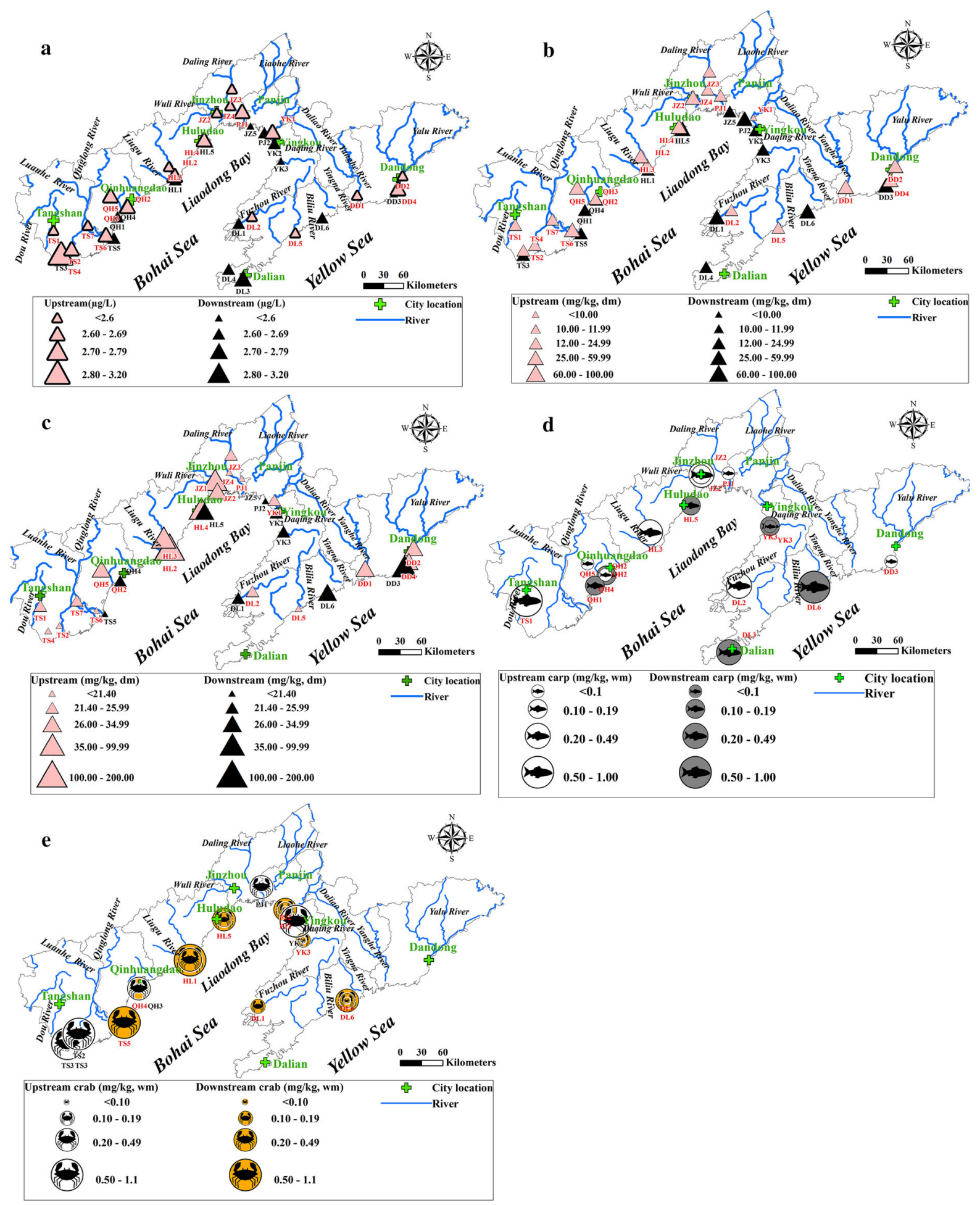

Fig. 2 Spatial distribution of $\mathrm{Pb}$ concentrations in the surface waters (a), sediments (b), soils (c), carp (d) and crabs (e) collected from the upstream and downstream regions of the coastal watersheds along the NBYS in China 
which indicated that the water quality in this region is not poor enough to have subtle or chronic adverse effects on coastal wildlife or human health (SEPAC 1999).

Relatively large $[\mathrm{Pb}]$ was observed in the downstream water of the rivers entering the Yellow (DL3) and Bohai Seas (DL1) near Dalian. The discharge of industrial wastewater and sewage as well as the $\mathrm{Zn}$ smelting factory in Dalian is most likely responsible for the observed $\mathrm{Pb}$ contamination (Meng et al. 2006). In addition, historical atmospheric deposition of $\mathrm{Pb}$ from automobile exhaust in Dalian could explain the contamination ( $\mathrm{Li}$ et al. 2009). All of the downstream water that was collected along the NBYS had mean $[\mathrm{Pb}]$ that exceeded the class I Chinese sea water quality standard of $1 \mu \mathrm{g} \mathrm{Pb} / \mathrm{L}$. The class I standard is applicable to national nature reserves but is lower than the class II Chinese seawater quality standard of $5 \mu \mathrm{g} \mathrm{Pb} / \mathrm{L}$ that is applicable to drinking water and the water in the habitats of rare animals. Therefore, the upstream and downstream water in the watersheds along the NBYS was contaminated with $\mathrm{Pb}$. Although the $\mathrm{Pb}$ contamination of the water near the cities could result from the historical atmospheric deposition of automobile exhaust containing $\mathrm{Pb}$ and wastewater discharges due to recent industrialization, urbanization and automobile exhaust (Cheng and $\mathrm{Hu} 2010$ ), some of the rivers that were further from cities, such as the Biliu, Liugu, Fuzhou and Luanhe Rivers, also contained relatively large $[\mathrm{Pb}]$. Because $\mathrm{Pb}$ could be transported by atmospheric circulation, these rivers likely received $\mathrm{Pb}$ from the atmosphere (Yi et al. 2012). Thus, the elevated $[\mathrm{Pb}]$ in the water potentially indicated the short-term effects of $\mathrm{Pb}$ released to the environment. The $[\mathrm{Pb}]$ in the Dou and Daliao Rivers along the North Bohai Sea that were reported in this study was greater than those reported in previous studies (Table 3), which indicates that the emission of $\mathrm{Pb}$ in these watersheds has recently increased.

\section{Surface sediments}

The mean $\pm \mathrm{SD}$ of the $[\mathrm{Pb}]$ was $24.52 \pm 9.20 \mathrm{mg} / \mathrm{kg}$, $\mathrm{dm}$, with a range of $9.50-48.49 \mathrm{mg} / \mathrm{kg}$, dm (Table 2). The mean $[\mathrm{Pb}]$ was not significantly greater in the upstream sediments $(24.92 \mathrm{mg} / \mathrm{kg}, \mathrm{dm})$ than in the downstream sediments $(23.93 \mathrm{mg} / \mathrm{kg}, \mathrm{dm} ; p>0.05)$. The greatest $[\mathrm{Pb}](43.36 \mathrm{mg} / \mathrm{kg}, \mathrm{dm})$ in the upstream sediments was observed in the Wuli River (HL4;
Fig. 2b). Several old industrial factories, such as the Huludao Zinc Plant (the largest zinc smelting plant in Asia that was established in 1935) and the Jinzhou Chemical Refinery Plant (which was established in 1937), are located along the river and could be responsible for the large $[\mathrm{Pb}]$ in the upstream sediments (Luo et al. 2010; Zheng et al. 2008; Zhang et al. 2012). The largest $[\mathrm{Pb}]$ in the downstream sediments $(48.49 \mathrm{mg} / \mathrm{kg}$, dm) was observed near Huludao (HL5), which is evidence of long-term releases due to industrial activities within the watersheds in Huludao (Zhang et al. 2012; Luo et al. 2010; Zheng et al. 2008). Generally, the $[\mathrm{Pb}]$ in the downstream sediments of the rivers entering Liaodong Bay was relatively large (Fig. 2b).

Only one sample of sediment contained $\mathrm{a}[\mathrm{Pb}]$ that was less than the background concentration of $11.5 \mathrm{mg} / \mathrm{kg}$, dm (Luo et al. 2010). However, except for the upstream sediments in the Wuli (HL4), Daling (JZ2) and Liugu Rivers (HL2, HL3) and in the downstream sediment of the river entering the Bohai Sea (HL5), most sediments had a [Pb] that was less than the limit for potential adverse effects to benthic invertebrates, including the "Threshold Effect Level" (TEL) and the "Effect Range Low" (ERL) concentrations (Table 4). Based on the sediment quality guidelines (SQGs) established by the US EPA, the $[\mathrm{Pb}]$ observed in all sediments was classified as "unpolluted," which is defined as $[\mathrm{Pb}]<110 \mathrm{mg} / \mathrm{kg}$, $\mathrm{dm}$ (Burton 2002). Furthermore, the $[\mathrm{Pb}]$ that is associated with adverse effects in benthic invertebrates $(35 \mathrm{mg} / \mathrm{kg}, \mathrm{dm})$ was exceeded in $14.3 \%$ of the sediment samples (Table 4). Therefore, a potential risk exists in some sediments, especially those in the Huludao coastal watershed. The mean EF value for $\mathrm{Pb}$ in the sediments along the NBYS was 2.41, and all of the sediments had EF values that were $>1.5$. These values indicated that human activities were the main sources of $\mathrm{Pb}$ in the sediments. The $\mathrm{EF}$ of the downstream sediments was significantly greater than that of the upstream sediments, which suggested that the human activities in the downstream areas likely caused the observed enrichment. Compared with the results of previous studies (Table 3 ), the $[\mathrm{Pb}]$ in the sediments in the estuaries around Liaodong Bay was relatively high. This finding indicates the ongoing discharge of $\mathrm{Pb}$ into the rivers. Thus, more effective abatement measures should be taken. However, the $[\mathrm{Pb}]$ in the sediments from the Wuli River and Jinzhou 
Table 3 Comparison of the $\mathrm{Pb}$ concentrations in the water $(\mu \mathrm{g} / \mathrm{L})$, sediments $(\mathrm{mg} / \mathrm{kg}, \mathrm{dm})$, soils $(\mathrm{mg} / \mathrm{kg}, \mathrm{dm})$ and biota $(\mathrm{mg} / \mathrm{kg}, \mathrm{wm})$ that were collected from the coastal watersheds of the NBYS in China in the present and previous studies

\begin{tabular}{|c|c|c|c|c|}
\hline Sample type & Sampling location & Sampling size & Mean $\pm \mathrm{SD}$ & References \\
\hline River water & CNBYS & 21 & $2.64 \pm 0.14$ & The present study \\
\hline Marine water & CNBYS & 15 & $2.62 \pm 0.04$ & The present study \\
\hline River water & Dou River & 7 & 2.78 & Gong (2009) \\
\hline River water & Luan River & 10 & 14.22 & Li and Liu (2009) \\
\hline River water & Daliao River & 7 & 1.86 & Liu et al. (2008) \\
\hline Marine water & Jinzhou Bay & 9 & 1.16 & Li et al. (2008) \\
\hline Marine water & North Yellow Sea & 39 & 0.4 & Tian et al. (2009) \\
\hline Marine water & Bohai Sea & 42 & 1.05 & Tian et al. (2009) \\
\hline River sediment & CNBYS & 21 & $24.92 \pm 9.29$ & The present study \\
\hline Marine sediment & CNBYS & 14 & $23.93 \pm 9.42$ & The present study \\
\hline River sediment & Luan River & 10 & 38.29 & Liu et al. (2009) \\
\hline River sediment & Wuli River & 20 & 80.5 & Zheng et al. (2008) \\
\hline Marine sediment & Yalu Estuary & 48 & 32.6 & Gao et al. (2008) \\
\hline Marine sediment & Estuaries around Liaodong Bay & 41 & 23.94 & Zhou et al. (2004) \\
\hline Marine sediment & Jinzhou Bay & 14 & 753.2 & Zhang et al. (2008) \\
\hline Marine sediment & Liaodong Bay & 56 & 20.4 & Hu et al. (2010) \\
\hline Soil & CNBY & 31 & $34.83 \pm 31.09$ & The present study \\
\hline Soil & Tangshan & 32 & 25.08 & Cui et al. (2011) \\
\hline Soil & Huludao & 240 & 49.48 & Li et al. (2006) \\
\hline Soil & Jinzhou & 60 & 348.67 & Xiao et al. (2010) \\
\hline Soil & Dalian & - & 24.5 & Liu (2006) \\
\hline Soil & Dandong & - & 14.5 & Liu (2006) \\
\hline River carp & CNBYS & 10 & $0.24 \pm 0.28$ & The present study \\
\hline Marine carp & CNBYS & 7 & $0.25 \pm 0.25$ & The present study \\
\hline River crab & CNBYS & 6 & $0.58 \pm 0.27$ & The present study \\
\hline Marine crab & CNBYS & 22 & $0.26 \pm 0.27$ & The present study \\
\hline Pomfret & Sea near Huludao & 2 & 0.133 & Yue and Shi (2001) \\
\hline Blue-spot sierra & Sea near Huludao & 4 & 0.09 & Yue and Shi (2001) \\
\hline Gobies & Sea near Huludao & 3 & 0.159 & Yue and Shi (2001) \\
\hline Hairy clam & Sea near Huludao & 3 & 0.391 & Yue and Shi (2001) \\
\hline Mussel & Sea near Huludao & 2 & 0.351 & Yue and Shi (2001) \\
\hline Chinese clam & Sea near Huludao & 2 & 0.619 & Yue and Shi (2001) \\
\hline Mussel & Liao River Estuary & 3 & 0.353 & Yue and Shi (2001) \\
\hline Wolf goby & Liao River Estuary & 1 & 0.17 & Ma et al. (1999) \\
\hline Crab & Liao River Estuary & 1 & 1.21 & Ma et al. (1999) \\
\hline Clam & Liao River Estuary & - & 0.21 & Ma et al. (1999) \\
\hline Clam & Jinzhou Bay & - & 0.4 & Wan et al. (2009) \\
\hline
\end{tabular}

- Data are not available

Bay is currently lower than the concentrations that have been reported historically, likely due to the efforts that have been taken to reduce pollution in the last few decades (Baptista and Smith 2000).

\section{Soil}

The mean soil $[\mathrm{Pb}]$ in the upstream areas of the coastal rivers along the NBYS was $40.23 \mathrm{mg} / \mathrm{kg}$, dm, with a 
Table 4 Guidelines for lead concentrations in water, sediment, soil and biota

\begin{tabular}{|c|c|c|c|}
\hline Sample & Background level and standard & Concentration & Reference \\
\hline \multirow[t]{8}{*}{ Water $(\mu \mathrm{g} / \mathrm{L})$} & Chinese sea water quality standard, class I & 1 & SEPAC (1997) \\
\hline & Chinese sea water quality standard, class II & 5 & SEPAC (1997) \\
\hline & Chinese sea water quality standard, class III & 10 & SEPAC (1997) \\
\hline & Chinese surface water standard, class I & 10 & SEPAC (1999) \\
\hline & Chinese surface water standard, class II & 10 & SEPAC (1999) \\
\hline & Chinese surface water standard, class III & 50 & SEPAC (1999) \\
\hline & $\begin{array}{l}\text { Criterion Maximum Concentration (acute effects) in salty } \\
\text { water }\end{array}$ & 210 & USEPA (2006) \\
\hline & $\begin{array}{l}\text { Criterion continuous Concentration (chronic effects) in salty } \\
\text { water }\end{array}$ & 8.1 & USEPA (2006) \\
\hline \multirow{7}{*}{$\begin{array}{l}\text { Sediment }(\mathrm{mg} / \mathrm{kg} \text {, } \\
\mathrm{dm})\end{array}$} & Background concentration & 11.5 & Luo et al. (2010) \\
\hline & Sediment primary standard & 60 & CSBTS (2002) \\
\hline & Sediment quality guideline & 170 & Giesy and Hoke (1990) \\
\hline & Threshold effect level (TEL) & 35 & Burton (2002) \\
\hline & Probable effect level (PEL) & 91.3 & Burton (2002) \\
\hline & Effect range low (ERL) & 35 & Burton (2002) \\
\hline & Effect range median (ERM) & 110 & Burton (2002) \\
\hline \multirow[t]{5}{*}{ Soil (mg/kg, dm) } & Maximum limit permissible level & 300 & $\begin{array}{l}\text { Kabata-Pendias and Pendias } \\
\text { (2001) }\end{array}$ \\
\hline & Background level in Liaoning & 21.4 & Ma et al. (1999) \\
\hline & Soil quality standard, class I & 35 & SEPAC (1995) \\
\hline & Soil quality standard, class II & 300 & SEPAC (1995) \\
\hline & Soil quality standard, class III & 500 & SEPAC (1995) \\
\hline \multirow[t]{5}{*}{ Biota $(\mathrm{mg} / \mathrm{kg}, \mathrm{wm})$} & Safety criteria for sea food in China & 0.5 & CMH (2005) \\
\hline & Maximum limit permissible level of $\mathrm{Pb}$ for fish & 0.3 & EC (2006) \\
\hline & $\begin{array}{l}\text { The Category I of } \mathrm{Pb} \text { of Marine biological quality for } \\
\text { crustaceans }\end{array}$ & 0.1 & SOAC (2001) \\
\hline & $\begin{array}{l}\text { The Category II of } \mathrm{Pb} \text { of Marine biological quality for } \\
\text { crustaceans }\end{array}$ & 2 & SOAC (2001) \\
\hline & $\begin{array}{l}\text { The Category III of Pb of Marine biological quality for } \\
\text { crustaceans }\end{array}$ & 6 & SOAC (2001) \\
\hline
\end{tabular}

range of $16.79-164.58 \mathrm{mg} / \mathrm{kg}, \mathrm{dm}$. In addition, the mean soil $[\mathrm{Pb}]$ in the downstream areas was 23.48 $\mathrm{mg} / \mathrm{kg}(\mathrm{dm})$, with a range of $10.55-37.19 \mathrm{mg} / \mathrm{kg}(\mathrm{dm})$ (Table 2). The mean soil [Pb] was significantly greater in the upstream areas than in the downstream areas $(p<0.05)$. The greatest $[\mathrm{Pb}](164.58 \mathrm{mg} / \mathrm{kg}, \mathrm{dm})$ was observed in the upstream area of the Liugu River (HL2). The large difference in the SDs of the $[\mathrm{Pb}]$ between the upstream and downstream soils potentially resulted from different humans activities in the upstream and downstream areas. The spatial distribution of the $[\mathrm{Pb}]$ in the soils was similar to that observed for the sediments. The greatest $[\mathrm{Pb}]$ in the soils was observed in the upstream areas of the coastal rivers along the Liaodong Bay and in the northern portion of the Bohai Sea, including the Liugu (HL2, HL3), Wuli (HL4) and Daling Rivers (JZ4). Of these rivers, the Liugu River was the most remote from large cities and chemical factories (Fig. 2c). The oil fields in Suizhong are reported to be the main sources of $\mathrm{Pb}$ in the soils of the Liugu Watershed. For the Wuli and Daling watersheds, industrial emissions are most likely responsible for the soil $\mathrm{Pb}$ contamination (Zhang et al. 2012; Lu et al. 2010; Zhang et al. 2009; Hršak et al. 2000).

Approximately $37 \%$ of the soils, mainly from upstream regions, had a $[\mathrm{Pb}]$ that exceeded the background concentration of $21.4 \mathrm{mg} / \mathrm{kg}$ (dm) (Fig. 2c; 
Table 4). In addition, $19 \%$ of the upstream soils and $10 \%$ of the downstream soils had a $[\mathrm{Pb}]$ that exceeded the class I Chinese soil quality standard of $35 \mathrm{mg} \mathrm{Pb} / \mathrm{kg}$, $\mathrm{dm}$, which is applicable for protecting the natural reserve and drinking water source regions. The concentrations of lead in all of the soils were less than the standard II Chinese soil quality (level of $300 \mathrm{mg} / \mathrm{kg}$, dm, which is the limit for human health and the maximum permissible [Pb] for European soils $(300 \mathrm{mg} / \mathrm{kg}$, dm; Table 4). The $[\mathrm{Pb}]$ in the soils along the NBYS watersheds was not high enough to be hazardous to human health. However, the $[\mathrm{Pb}]$ in some of the soils was greater than the regional background. In addition, $\mathrm{Pb}$ can be absorbed by humans through the consumption of crops that are planted in Pb-contaminated soils. Furthermore, changing environmental conditions can cause the release of $\mathrm{Pb}$ in soils to the environment, which could result in the secondary pollution of surface water and sediments (Segura et al. 2006). Therefore, longterm monitoring of soil $\mathrm{Pb}$ is necessary to prevent potential risk. The mean enrichment factor $(\mathrm{EF})$ for $\mathrm{Pb}$ in the soils along the NBYS was 2.22, and the mean EF for the upstream soils was significantly greater than that of the downstream soils. Of all of the samples, $66.7 \%$ had EFs that exceeded 1.5. This result suggests that the enrichment of $\mathrm{Pb}$ mainly resulted from human activities in the upstream regions.

The soil $[\mathrm{Pb}]$ in Jinzhou that was observed in this study was significantly lower than that reported previously (Fig. 2c; Table 3). This finding potentially resulted from the differences between the sampling locations. In previous studies, the sampling locations in Jinzhou were near the Jinzhou Ferroalloy Factory, while the sampling locations in the present study were farther away from the Huludao Zinc Smelting Factory (Xiao et al. 2010; Li et al. 2006).

Based on the spatial distribution of $[\mathrm{Pb}]$ in the surface water, sediments and soils (Fig. 2a-c), it was determined that if an upstream site within a watershed had an elevated sediment $[\mathrm{Pb}]$, the corresponding downstream site within the watershed would also have a relatively high $[\mathrm{Pb}]$ in the water. This observation implies that the upstream sediment may be a source of $\mathrm{Pb}$ for downstream water due to the release of $\mathrm{Pb}$ from the sediment and its transport by water. Consequently, as shown in Table 5, the $[\mathrm{Pb}]$ in the water at any site was not significantly and positively correlated with the $[\mathrm{Pb}]$ in the sediment at the same site $(p>0.05$; Table 5). In
Table 5 Correlation between the concentrations of different metals in the biota, surface water, soil and sediment

\begin{tabular}{lrlll}
\hline $\begin{array}{l}\text { Pearson } \\
\text { correlation }\end{array}$ & $\begin{array}{l}\mathrm{Pb}- \\
\text { water }\end{array}$ & $\begin{array}{l}\mathrm{Pb}- \\
\text { sediment }\end{array}$ & $\begin{array}{l}\mathrm{Pb}- \\
\text { soil }\end{array}$ & $\begin{array}{l}\mathrm{Pb}- \\
\text { biota }\end{array}$ \\
\hline $\mathrm{Pb}$-water & 1.00 & & & \\
$\mathrm{~Pb}$-sediment & -0.09 & 1.00 & & \\
$\mathrm{~Pb}$-soil & -0.18 & $0.57 *$ & 1.00 & \\
$\mathrm{~Pb}$-biota & 0.07 & -0.27 & -0.06 & 1.00 \\
\hline
\end{tabular}

* Correlation is significant at the 0.01 level (2-tailed)

addition, the $[\mathrm{Pb}]$ in the sediment at a given site increased as the soil $[\mathrm{Pb}]$ increased. Furthermore, Pearson's correlation matrix indicated that the sediment $[\mathrm{Pb}]$ was significantly correlated with the soil $[\mathrm{Pb}]$. These results indicate that the sediments and soils in the studied area could have the same sources of $\mathrm{Pb}$.

Biota

The $[\mathrm{Pb}]$ in the carp ranged from 0.04 to $0.95 \mathrm{mg} / \mathrm{kg}$, wm, with a mean of $0.24 \pm 0.26 \mathrm{mg} / \mathrm{kg}$, wm (Table 2). The mean $[\mathrm{Pb}]$ in the carp from the downstream areas $(0.25 \mathrm{mg} / \mathrm{kg}$, wm $)$ was not significantly greater than that from the upstream areas $(0.24 \mathrm{mg} / \mathrm{kg}$, wm; $p<0.05)$. The greatest $[\mathrm{Pb}]$ $(0.95 \mathrm{mg} / \mathrm{kg}, w \mathrm{w})$ in the upstream carp occurred in the Daliao River at Tangshan (TS1), while the greatest $[\mathrm{Pb}](0.79 \mathrm{mg} / \mathrm{kg}$, wm $)$ that was observed in the carp from the downstream area occurred at the coastal site in Dalian (DL6; Fig. 2d). The large variations in the habitat and dietary sources may account for the large SD that was observed for $[\mathrm{Pb}]$ in carp. The $[\mathrm{Pb}]$ in $90 \%$ of the carp samples was less than the maximum permissible concentration of $0.5 \mathrm{mg} / \mathrm{kg}$, wm, for the edible portions of the marine biota in China, and the $[\mathrm{Pb}]$ in $70.6 \%$ of the carp samples was lower than the maximum permissible concentration of $\mathrm{Pb}$ in fish according to the regulations of European countries that are designed to protect humans from the adverse effects of $\mathrm{Pb}$ (Table 4). The HRIs that accumulated in the local residents through the consumption of biota serve as important measures for evaluating the potential risks and adverse health effects of $\mathrm{Pb}$ and are listed in Table 2.

The mean $[\mathrm{Pb}]$ in the crab tissues was $0.33 \mathrm{mg} / \mathrm{kg}$, wm, with a range of $0.0024-1.03 \mathrm{mg} / \mathrm{kg}$, wm. The 
mean $[\mathrm{Pb}]$ in the crabs from the upstream areas $(0.58 \mathrm{mg} / \mathrm{kg}$, wm) was significantly greater than that from the downstream areas $(0.26 \mathrm{mg} / \mathrm{kg}$, wm; $p<0.05$; Table 2). The difference in habitat type (shallow hard-bottom intertidal or subtidal habitats) and diet (macroalgae, salt marsh grasses and small invertebrates) between the upstream and downstream areas could result in the observed differences in the $[\mathrm{Pb}]$ in the crabs (Maria et al. 2012; Preez et al. 1993). Relatively high $[\mathrm{Pb}]$ was found in the crabs that were collected from the upstream areas of the Shuanglong $(0.80 \mathrm{mg} / \mathrm{kg}$, wm) and Daliao $(0.88 \mathrm{mg} / \mathrm{kg}$, wm) Rivers and from the downstream areas of the Luanhe $(1.03 \mathrm{mg} / \mathrm{kg}$, wm) and Liugu $(0.76 \mathrm{mg} / \mathrm{kg}$, wm) Rivers (Fig. 2e). All of the crabs had $[\mathrm{Pb}]$ that exceeded category I of the Chinese marine biological quality standard for $\mathrm{Pb}$ in crustaceans $(0.1 \mathrm{mg} / \mathrm{kg}$, wm), which is applicable to marine fishing, agriculture and natural reserves (Table 4). However, none of the crabs had a $[\mathrm{Pb}]$ that exceeded the category II Chinese marine biological quality standard for $\mathrm{Pb}$ in crustaceans $(2.0 \mathrm{mg} / \mathrm{kg}$, wm), which is applicable to the water supply for general industry and scenic areas (SOAC 2001). In addition, $66.7 \%$ of the upstream crabs and $14.3 \%$ of the downstream crabs had $[\mathrm{Pb}]$ that was greater than the regulatory limit for human consumption $(0.5 \mathrm{mg} / \mathrm{kg}$, wm). Compared with the results presented in the literature, the river crabs in this study had a relatively large mean [Pb] (Table 3 ). However, the marine crabs in this study had a lower mean $[\mathrm{Pb}]$ than previously collected seafood near Huludao and greater concentrations and than that in seafood that was previously collected from the Liao River Estuary and Jinzhou Bay.

Pearson's correlations indicated that none of the $[\mathrm{Pb}]$ in the carp and crabs was significantly correlated with the $[\mathrm{Pb}]$ in the water, sediments or soils. Based on the spatial distribution of $[\mathrm{Pb}]$ in the water, sediments, soils and biota (Fig. 2a-e), the areas with elevated $[\mathrm{Pb}]$ in the water, sediments and soils did not correspond to the areas with elevated $[\mathrm{Pb}]$ in carp and crabs. Because the $[\mathrm{Pb}]$ in the carp and crabs is mainly bioaccumulated through their diet rather than from the water and sediments (Sary and Mohammadi 2012; Neslihan and Kumbur 2010), the [Pb] in the water and sediments did not represent the bioavailable fraction of $\mathrm{Pb}$. To gain insight regarding the origin of $\mathrm{Pb}$ in aquatic biological populations, environmental and biological factors should be considered. Long-term investigation should be conducted to understand the biogeochemistry of $\mathrm{Pb}$ in the environmental matrix of coastal watersheds and the bioavailability of $\mathrm{Pb}$ and its ecological risks (Luo et al. 2012).

\section{Human health risks}

The $[\mathrm{Pb}]$ in the water and biota was lower than the threshold concentrations that can cause adverse effects in humans. Because the calculated HRI of the water in this study was 0.002 (Table 2), which is less than the criterion value of 1.0, it was assumed that the potentially exposed population was not at risk.

The mean HRI for carp was only 0.01 , which suggested that the risks of human exposure to $\mathrm{Pb}$ through carp consumption are generally small. However, all of the carp had BAF values that significantly exceeding 1.0. Moreover, $25 \%$ of the carp samples had BAF values that exceeded 100, indicating that these carp had significant potential for accumulating $\mathrm{Pb}$ from their surroundings. Because the BSAFs for $\mathrm{Pb}$ were $<1.0$, the carp did not accumulate significant amounts of $\mathrm{Pb}$ from the sediments. Based on the BAF and BASF values derived for $[\mathrm{Pb}]$, it was concluded that carp mainly accumulate $\mathrm{Pb}$ from the water. Compared with the previously reported $[\mathrm{Pb}]$ in fish (Table 3), the mean $[\mathrm{Pb}]$ in the muscles of carp in this study was relatively high. Despite the relatively small HRIs (because carp is one of the most popular species consumed by people in China), the greater ability of carp to accumulate $\mathrm{Pb}$ from their surroundings could pose a potential risk to human health and to the health of other predators.

Most crabs from the upstream areas contained $[\mathrm{Pb}]$ that exceeded the permissible limit. Consequently, humans should not consume these carp. The greater BAF (128.37) and the relatively smaller BSAF (0.02) for the $\mathrm{Pb}$ in the crabs indicated that they accumulated more $\mathrm{Pb}$ from the water than from the sediments (Table 2). Compared with the BAFs for carp (94.09), the crabs were more capable of accumulating $\mathrm{Pb}$ from the water relative to the carp. The site-specific BAF for the upstream crabs was as high as 218.79 , which suggested a long-term potential risk for the consumption of crabs by humans. Fortunately, people in China do not commonly consume crabs, reducing their risks of $\mathrm{Pb}$ contamination. 


\section{Conclusions}

An overview of the $[\mathrm{Pb}]$ in the matrices within the coastal watersheds along the NBYS has been provided. The mean $[\mathrm{Pb}]$ was $2.63 \mu \mathrm{g} / \mathrm{L}$ in the water, $23.84 \mathrm{mg} / \mathrm{kg}, \mathrm{dm}$, in the sediments, $34.83 \mathrm{mg} / \mathrm{kg}$, dm, in the soils, $0.24 \mathrm{mg} / \mathrm{kg}$, wm, in the carp and 0.33 $\mathrm{mg} / \mathrm{kg}$, wm, in the crabs. The ranges of the $[\mathrm{Pb}]$ in the water, soils, sediments, carp and crabs were $2.5-3.2 \mu \mathrm{g} / \mathrm{L}, \quad 11-165 \mathrm{mg} / \mathrm{kg}, \mathrm{dm}, \quad 9.5-49 \mathrm{mg} / \mathrm{kg}$, $\mathrm{dm}, 0.041-0.95 \mathrm{mg} / \mathrm{kg}$, wm and $0.0024-1.0 \mathrm{mg} / \mathrm{kg}$, $w m$, respectively. There was no difference in the $[\mathrm{Pb}]$ between the upstream and downstream water. All of the water samples had $[\mathrm{Pb}]$ that was less than the class II Chinese sea water quality standard, which indicated that the water quality in this region was not poor enough to have subtle or chronic adverse effects on the coastal wildlife or human health. The $[\mathrm{Pb}]$ in the sediments indicates that the area along the NBYS is relatively unpolluted by $\mathrm{Pb}$. The $[\mathrm{Pb}]$ in the sediments and soils at Huludao along Liaodong Bay was greater than that in the other sediments. All of the soils had $[\mathrm{Pb}]$ that was less than the class II Chinese soil quality standard, and the maximum permissible level for European soils, which indicates that the $[\mathrm{Pb}]$ in the soils should have little effect on wildlife, agriculture or humans. Enrichment factors showed that human activities were the major factors for enriching $\mathrm{Pb}$ in sediments and soils. The $[\mathrm{Pb}]$ in the sediments and soils was significantly correlated. In addition, the small HRIs for the $\mathrm{Pb}$ in the water and biota indicated that the human health risk of $\mathrm{Pb}$ exposure through the consumption of water and biota consumption is generally small. However, because of the significant capabilities of carp and crab to accumulate $\mathrm{Pb}$ from their environments, shown by their BAFs, the potential hazard of $[\mathrm{Pb}]$ should be of concern regarding the consumption of this biota by humans and predators. When comparing this $[\mathrm{Pb}]$ with previously reported ones, the emissions of $\mathrm{Pb}$ to the studied coastal areas have not been effectively prevented. Thus, long-term monitoring and environmental management are still needed.

Acknowledgments This research was supported by the National Natural Science Foundation of China under Grant Nos. 41271502 and 41071355, National Fundamental Field Study Program with Grant No. 2013FY111100, Strategic Priority Research Program of the Chinese Academy of Sciences, Grant No. XDB03030504, the National International
S\&T Cooperation Program under Grant No. 2012DFA91150, the Einstein Professorship Program, CAS, and the Project of the State Key Lab of Urban and Regional Ecology with Grant No. SKLURE2008-1-04. Portions of the research were supported by a Discovery Grant from the National Science and Engineering Research Council of Canada (Project No. 6807).

\section{References}

Arnason, J. G., \& Fletcher, B. A. (2003). A $40+$ year record of $\mathrm{Cd}, \mathrm{Hg}, \mathrm{Pb}$ and $\mathrm{U}$ deposition in sediments of Patroon Reservoir, Albany County, NY, USA. Environmental Pollution, 123, 383-391.

Baptista, N. J., \& Smith, B. J. (2000). Heavy metal concentrations in surface sediments in a nearshore environment, Jurujuba Sound, Southeast Brazil. Environmental Pollution, 109, 1-9.

Burton, G. A. (2002). Sediment quality criteria in use around the world. Limnology, 3, 65-75.

Cheng, H., \& Hu, Y. (2010). Lead (Pb) isotopic fingerprinting and its applications in lead pollution studies in China: A review. Environmental Pollution, 158, 1134-1146.

CMH (2005). Hygienic standard for fresh and frozen marine products of animal origin (GB 2733-2005) (in Chinese).

CSBTS (2002). National standards GB 18668-2002-marine sediment quality (GB 18668-2002). (pp. 10). The People's Republic of China (in Chinese).

Cui, X., Luan, W., Niu, Y., Li, S., \& Song, Z. (2011). An assessment of the heavy metal pollution and potential ecological hazards in urban soil of Tangshan city. Geology of China, 38(5), 1379-1386. (in Chinese).

Dong, A. G., Zhai, S. K., Zabel, M., \& Yu, Z. H. (2009). The distribution of heavy metal contents in surface sediments of the Changjiang Estuary in China and surrounding coastal areas. Acta Oceanological Sinica, 31(6), 54-68.

EC (2006). Setting maximum levels for certain contaminants in foodstuffs. EU Commission Regulation (EC) No1881/ 2006.

Feng, H., Han, X., Zhang, W., \& Yu, L. (2004). A preliminary study of heavy metal contamination in Yangtze River intertidal zone due to urbanization. Marine Pollution Bulletin, 49, 910-915.

Feng, H., Jiang, H., Gao, W., Weinstein, M. P., Zhang, Q., Zhang, W., et al. (2011). Metal contamination in sediments of the western Bohai Bay and adjacent estuaries, China. Journal of Environmental Management, 92, 1185-1197.

Gao, X., \& Chen, C. T. A. (2012). Heavy metal pollution status in surface sediments of the coastal Bohai Bay. Water Research, 46, 1901-1911.

Gao, J., Li, J., Wang, Z., Wang, Y., Bai, F., \& Cheng, Y. (2008). Heavy metal distribution and their influence factors in sediments of Yalu River Estuary and its adjacent Sea area. Geochimica (Beijing), 37(5), 430-438. (in Chinese).

Gao, J. Q., Li, X. W., \& Zhao, J. L. (2006). 2000 Chinese total diet study-the dietary lead and cadmium intakes. Jounal of Hygiene Research, 35(6), 750-754. (in Chinese).

Ghrefat, H., \& Yusuf, N. (2006). Assessing Mn, Fe, Cu, Zn, and Cd pollution in bottom sediments of Wadi Al-Arab Dam, Jordan. Chemosphere, 65, 2114-2121. 
Giesy, J. P., \& Hoke, R. A. (1990). Freshwater sediment quality criteria: toxicity bioassessment. In R. Baudo, J. P. Giesy, \& M. Muntao (Eds.), Sediment Chemistry and toxicity of inplace pollutants (p. 391). Ann Arbor, MI: Lewis publishers.

Gobeil, C., Rondeau, B., \& Beaudin, L. (2005). Contribution of municipal effluents to metal fluxes in the St. Lawrence River. Environmental Science \& Technology, 39, 456464.

Gong, X. (2009). Water quality monitoring and pollution source analying of Dou River in city. Journal of Hebei Polytechnic University, 31(4), 132-136. (in Chinese).

Han, Y. M., Du, P. X., Cao, J. J., \& Posmentier, E. S. (2006). Multivariate analysis of heavy metal contamination in urban dusts of Xi'an, Central China. Science of the Total Environment, 355, 176-186.

Hršak, J., Fugaš, M., \& Vadjic, V. (2000). Soil contamination by $\mathrm{Pb}, \mathrm{Zn}$ and $\mathrm{Cd}$ from a lead smelter. Environmental Monitoring and Assessment, 60(3), 59-366.

Hu, N., Shi, X., Huang, P., \& Liu, J. H. (2010). Distribution of metals in surface sediments of Liaodong Bay, Bohai Sea. China Environmental Science, 30(3), 380-388. (in Chinese).

Jiang, X., Teng, A., Xu, W., \& Liu, X. (2014). Distribution and pollution assessment of heavy metals in surface sediments in the Yellow Sea. Marine Pollution Bulletin, 83, 366-375.

Kabata-Pendias, A., \& Pendias, H. (2001). Trace elements in soils and plants (3rd ed.). Boca Raton, FL: CRC Press.

Khan, M. U., Malik, R. N., \& Muhammad, S. (2013). Human health risk from Heavy metal via food crops consumption with wastewater irrigation practices in Pakistan. Chemosphere, 93, 2230-2238.

Kimbrough, K. L., \& Lauenstein, G. G. (2006). Trace metal analytical methods of the national status and trends program: 2000-2006. US Dept. Comm., NOAA Tech. Memo. 29, NOS NCCOS, Silver Spring, Maryland.

Li, Y., \& Liu, J. (2009). Health risk assessment on heavy metal pollution in the water environment of Luan River. Journal of Agro-Environment Science, 28(6), 1177-1184. (in Chinese).

Li, Y., Liu, Y., Liu, J., Zeng, G., \& Li, X. (2008). Effects of EDTA on lead uptake by Typha oreentalis Presl: A new lead-accumulating species in southern China. Bulletin of Environmental Contamination and Toxicology, 81(1), $36-41$.

Li, J., Sun, C., Li, Y., Li, J., Jin, D., \& Li, W. (2009). Concentration of lead in atmosphere and emission characteristics of pollution sources in China. Environmental Protection of Chemical Industry, 29(4), 376-380.

Li, L., Wang, Y., Zhang, D., \& Yi, Y. (2006). Spatial distribution of soil $\mathrm{Pb}$ and its pollution evaluation of Huludao City. Soils, 38(4), 465-469. (in Chinese).

Liu, Q. (2006). The research on heavy metals pollution in soils in major cities in North-east of China. Dalian: Dalian Technology University. (in Chinese).

Liu, J., Li, Y., Zhang, B., \& Cao, J. (2009). Ecological risk of heavy metals in sediments of the Luan River source water. Ecotoxicology, 208, 748-758.

Liu, J., Sun, Q., Mo, C., \& Guo, N. (2008). The pollution status and characteristics of Daliaohe Estuary and its adjacent sea area. Fisheries Science, 27(6), 286-289. (in Chinese).
Lu, C. A., Zhang, J. F., Jiang, H. M., Yang, J. C., Zhang, J. T., Wang, J.Z., et al. (2010). Assessment of soil contamination with $\mathrm{Cd}, \mathrm{Pb}$ and $\mathrm{Zn}$ and source identification in the area around the Huludao Zinc Plant. Journal of Hazardous Materials, 182(1-3), 743-748.

Lue, C., He, J., Fan, Q., \& Xue, H. (2011). Accumulation of heavy metals in wild commercial fish from the Baotou urban section of the Yellow River, China. Environmental Earth Sciences, 62(4), 679-696.

Luo, W., Lu, Y. L., Wang, T. Y., Hu, W. Y., Jiao, W. T., Naile, J. E., et al. (2010). Ecological risk assessment of arsenic and metals in sediments of coastal areas of northern Bohai and Yellow Seas, China. Ambio, 39(5-6), 367-375.

Luo, W., Wang, T. Y., Jiao, W. T., Hu, W. Y., Naile, J. E., Khim, J. S., et al. (2012). Mercury in coastal watersheds along the Chinese Northern Bohai and Yellow Seas. Journal of Hazardous Materials, 215, 199-207.

Ma, M., Hai, Z., Feng, Z., Guan, C., \& Chen, H. (1999). Study on the contents, temporal and spatial trends of the contaminants in the marine animals along the coastal area near the mouth of Shuangtaihe river, Liaodong Bay. Marine Environmental Science, 18, 61-64. (in Chinese).

Maria, G. A., Tumini, G., Imhof, A., \& Gervasio, S. (2012). Comparative study of lead accumulation in different organs of the freshwater crab zilchiopsis oronensis. Water, Air, and Soil pollution, 223(2), 617-624.

Meng, W., Zhai, S., Qin, Y., \& Zheng, B. (2006). Sources identification of heavy metals in core sediments of Bohai Bay. Marine Science Bulletin, 25(1), 62-69. (in Chinese).

Neslihan, D., \& Kumbur, Halil. (2010). Metals (Hg, Pb, Cu, and $\mathrm{Zn}$ ) Bioaccumulation in sediment, fish, and human scalp hair: A case study from the city of Mersin along the southern coast of Turkey. Biological Trace Element Research, 136(1), 55-70.

Ona, L. F., Melinda, A., Alberto, P., Prudente, J. A., \& Sigua, G. C. (2006). Levels of lead in urban soils from selected cities in a central region of the Philippines. Environmental Science and Pollution Research, 13, 177-183.

Patterson, C. C., \& Settle, D. M. (1976). Accuracy in Trace Analysis: Sampling, Sample Handling, and Analysis, US. National Bureau of Standards Special Publication 422, US, Government Printing Office, Washington DC, 321-351.

Preez, H. H., Steenkamp, V. E., \& Schoonbee, H. J. (1993). Bioaccumulation of zinc and lead in selected tissues and organs of the freshwater crab, Potamonautes warreni. Science of the Total Environment, Suppl Part 1, 469-478.

Sary, A. A., \& Mohammadi, M. (2012). Lead bioaccumulation and toxicity in tissues of economically fish species from river and marine water. Bulletin of Environmental Contamination and Toxicology, 89(1), 82-85.

Segura, R., Arancibia, V., Zuniga, M. C., \& Pasten, P. (2006). Distribution of copper, zinc, lead and cadmium concentrations in stream sediments from the Mapocho River in Santiago, Chile. Journal of Geochemical Exploration, 91(1-3), 71-80.

SEPAC. (1995). Environmental quality standard for soils, GB 15618-1995 (in Chinese).

SEPAC. (1997). Sea water quality standard (GB 3097-1997). GB 3097-1997 (in Chinese).

SEPAC. (1999). Environmental quality standard for surface water. GHZB 1-1999 (in Chinese). 
Sinex, S. A., \& Wright, D. A. (1988). Distribution of trace metals in the sediments and biota of Chesapeake Bay. Marine Pollution Bulletin, 19, 425-431.

SOAC. (2001). Marine biological quality (GB-1842-2001) (in Chinese).

Tao, J. H. (2006). Numerical simulation of aquatic Eco-environment of Bohai bay. Journal of Hydrodynamics Ser B, $18,34-42$.

Tian, L., Chen, H., Du, J., \& Wang, X. (2009). Factors influencing distribution of soluble heavy metals in North Yellow Sea surface seawaters. Journal of Ocean University of China, 39(4), 617-621. (in Chinese).

USEPA. (1992). Test methods for evaluating solid waste, physical/chemical methods. USEPA, SW-846, (3rd ed.). United States Environmental Protection Agency.

USEPA. (2006). National recommended water quality criteria. (nrwqc-2006.pdf). U.S. Environmental Protection Agency, Office of Water, Washington, DC. Retrieved February 17, 2009 from http://wmw.epa.gov/waterscience/criteria/ wqctable/.

Wan, L., Wang, N., Ding, Q., Zhang, Q., \& Yu, B. (2009). The distribution of heavy metal pollution in Jinzhou Bay, Bohai Sea. Fisheries Science, 28, 801-804. (in Chinese).

Wan, L., Wang, N. B., Li, Q. B., Zhou, Z. C., Sun, B., Xue, K., et al. (2008). Estival distribution of dissolved metal concentrations in Liaodong Bay. Bulletin of Environmental Contamination and Toxicology, 80(4), 311-314.

Wang, C. Y., \& Wang, X. L. (2007). Spatial distribution of dissolved $\mathrm{Pb}, \mathrm{Hg}, \mathrm{Cd}, \mathrm{Cu}$ and $\mathrm{As}$ in the Bohai Sea. Journal of Environmental Sciences, 19, 1061-1066.

Wang, C., Wang, X., Li, K., Liang, S., Su, R., \& Yang, S. (2010). The estimation of copper, lead, zinc and cadmium fluxes into the sea area of the East China Sea interferenced by terrigenous matter and their environmental capacities. Acta Oceanologica Sinica, 32(4), 62-74.

Xiao, Z. L., Qu, J., \& Cong, Q. (2010). Evaluation of heavy metal pollution in soil and vegetables around Jinzhou Ferroalloy Factory. Shandong Agriculture Sciences, 12, 64-66. (in Chinese).
Yi, Q., Dou, X. D., Huang, Q. R., \& Zhao, X. Q. (2012). Pollution Characteristics of $\mathrm{Pb}, \mathrm{Zn}, \mathrm{As}, \mathrm{Cd}$ in the Bijiang River. Procedia Environmental Sciences, 13, 43-52.

Yu, T., Zhang, Y., Hu, X., \& Meng, W. (2012). Distribution and bioaccumulation of heavy metals in aquatic organisms of different trophic levels and potential health risk assessment from Taihu lake, China. Ecotoxicology and Environmental Safety, 81, 55-64.

Yue, L., \& Shi, B. (2001). Monitoring the contaminated situation of the aquatic animals caused by heavy metals in the inshore maritime area of Hulu island. Environmental Monitoring in China, 17, 45-47. (in Chinese).

Zhang, J., \& Liu, C. L. (2002). Riverine composition and estuarine geochemistry of particulate metals in China-weathering features, anthropogenic impact and chemical fluxes. Estuarine, Coastal and Shelf Science, 54, 1051-1070.

Zhang, Z., Lu, X., Wang, Q., \& Zheng, D. (2009). Mercury, cadmium and lead biogeochemistry in the soil-plant-insect system in Huludao city. Bulletin of Environmental Contamination and Toxicology, 83(2), 255-259.

Zhang, Z., Song, X., Wang, Q., \& Lu, X. (2012). Cd and Pb contents in soil, plants, and grasshoppers along a pollution gradient in Huludao City, Northeast China. Biological Trace Element Research, 145(3), 403-410.

Zhang, Y., Wang, L., Huo, C., \& Guan, D. (2008). Assessment on heavy metals pollution in surface sediments in Jinzhou Bay. Marine Environmental Science, 27(2), 178-181. (in Chinese).

Zheng, N., Wang, Q., Liang, Z., \& Zheng, D. (2008). Characterization of heavy metal concentrations in the sediments of three freshwater rivers in Huludao City, Northeast China. Environmental Pollution, 154, 135-142.

Zhou, X., Wang, E., Liu, X., \& Wang, W. (2004). Environmental geochemistry of heavy metals in bottom sediments of the river mouths in Liaodong Bay. Geochimica (Beijing), 33(3), 286-290. 